\begin{tabular}{|} 
Ambiente \& Água - An Interdisciplinary Journal of Applied Science \\
ISSN 1980-993X - doi:10.4136/1980-993X \\
www.ambi-agua.net \\
E-mail: ambi.agua@gmail.com
\end{tabular}

\title{
Antibiotic resistance in surface waters from a coastal lagoon of Southern Brazil under the impact of anthropogenic activities
}

\author{
ARTICLES doi:10.4136/ambi-agua.2379
}

Received: 14 Feb. 2019; Accepted: 19 Jul. 2019

\section{Belize Leite $^{1 *(\mathbb{D})}$; Magda Antunes de Chaves ${ }^{1 \mathbb{D}}$; Athos Aramis Thopor Nunes ${ }^{1(\mathbb{D})}$ Louise Jank ${ }^{2}$; ; Gertrudes Corção 3}

\author{
${ }^{1}$ Programa de Pós-Graduação em Microbiologia Agrícola e do Ambiente, Laboratório de Bacteriologia, \\ Universidade Federal do Rio Grande do Sul (UFRGS), Rua Sarmento Leite, ${ }^{\circ}$ 500, CEP 90035-190, Porto \\ Alegre, RS, Brazil. E-mail: magda_antunes@hotmail.com, athostopor@gmail.com \\ ${ }^{2}$ Laboratório de Análises de Resíduos de Pesticidas e Medicamentos, Laboratório Nacional Agropecuário \\ (LANAGRO), Estrada Ponta Grossa, n³ 3036, CEP 91780-580, Porto Alegre, RS, Brazil. \\ E-mail: louise.jank@agricultura.gov.br \\ ${ }^{3}$ Instituto de Ciências Básicas e da Saúde, Departamento de Microbiologia, Imunologia e Parasitologia, \\ Universidade Federal do Rio Grande do Sul (UFRGS), Rua Sarmento Leite, ${ }^{\circ}$ 500, CEP 90035-190, Porto \\ Alegre, RS, Brazil. E-mail: corcao@ufrgs.br \\ *Corresponding author. E-mail: belize.leite@gmail.com
}

\begin{abstract}
Wastes arising from human activities can reach water bodies and contribute significantly to the presence of antibiotic resistant bacterial populations in aquatic environments. The objective of this study was to evaluate the cultivable antibiotic resistant bacterial populations from a coastal lagoon impacted by agriculture and urbanization activities. Water samples were collected in low and peak season and characterized regarding physicochemical variables, microbiological indicators and the presence of antimicrobial residues. In order to analyze the presence of resistant bacterial populations, the samples were grown in the presence of nalidixic acid, ceftazidime, imipenem and tetracycline. Genes associated with $\beta$-lactamic resistance

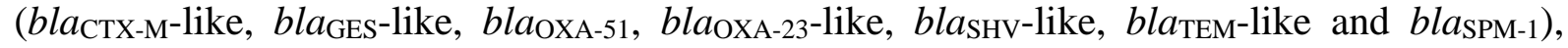
class $\mathrm{I}$ integron and efflux systems $(t e t \mathrm{~A}, t e t \mathrm{~B}, \operatorname{acr} \mathrm{A}, \operatorname{acr} \mathrm{B}, t o l \mathrm{C}, \operatorname{ade} \mathrm{A}, \operatorname{ade} \mathrm{B}, \operatorname{ade} \mathrm{R}, \operatorname{ade} \mathrm{S}$, mex $\mathrm{B}$, mex $\mathrm{D}$, mex $\mathrm{F}$ and mex $\mathrm{Y}$ ) were analyzed by conventional in vitro amplification. Although antimicrobials residues were below the detection limit, resistant bacteria and resistance determinants - bla $a_{\mathrm{GES}}$, class I integron, adeS, $a c r \mathrm{~A}, \operatorname{acr} \mathrm{B}, \operatorname{tol} \mathrm{C}, \operatorname{mex} \mathrm{B}, \operatorname{mex} \mathrm{F}$ - were present at almost all points, in both seasons and for all antimicrobials assessed. The high numbers of resistant bacteria counts observed after the antibiotic treatment were positively correlated to the urbanization effects on the Lagoon. Some resistant populations were even higher in the low season samples, indicating the importance of a systematic evaluation of antibiotic resistance on water resources.
\end{abstract}

Keywords: anthropic impact, antibiotic resistance, aquatic bacteria, estuary. 


\section{Resistência antibiótica nas águas superfíciais de uma lagoa costeira do Sul do Brasil sob impacto de atividades antropogênicas}

\section{RESUMO}

Resíduos oriundos de atividades humanas podem atingir corpos d'água e contribuir significativamente para a presença de populações bacterianas resistentes a antibióticos. $\mathrm{O}$ objetivo deste estudo foi avaliar populações de bactérias cultiváveis resistentes a antibióticos em uma lagoa costeira impactada por atividades como agricultura e urbanização. Amostras de água foram coletadas nos períodos de baixa e alta temporada e caracterizadas quanto a variáveis físico-químicas, indicadores microbiológicos e presença de resíduos de antimicrobianos. Para analisar a presença de populações bacterianas resistentes, as amostras foram crescidas na presença de ácido nalidíxico, ceftazidima, imipenem e tetraciclina. Genes de resistencia a $\beta$ -

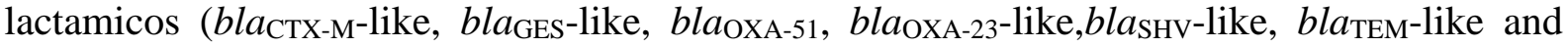
blasPM-1), de classe I integron e sistemas de efluxo (tet $\mathrm{A}, \operatorname{tet} \mathrm{B}, \operatorname{acr} \mathrm{A}, \operatorname{acr} \mathrm{B}, \operatorname{tol} \mathrm{C}, \operatorname{ade} \mathrm{A}, \operatorname{ade} \mathrm{B}$, ade $\mathrm{R}$, ade $\mathrm{S}, \operatorname{mex} \mathrm{B}, \operatorname{mex} \mathrm{D}, \operatorname{mex} \mathrm{F}$ and $m e x \mathrm{Y}$ ) foram analisados por amplificação in vitro. Embora não tenham sido encontrados níveis detectáveis de residuos de antimicrobianos nas amostras, bactérias resistentes estavam presentes em quase todos os pontos, em ambas as estações e para todos os antimicrobianos avaliados. A presença de populações bacterianas resistentes observada foi positivamente correlacionada aos efeitos da urbanização na Lagoa. Algumas populações resistentes foram ainda maiores na baixa temporada, indicando a importância de avaliar sistematicamente a resistência a antibióticos em corpos d'água.

Palavras-chave: bactérias aquáticas, estuário, impacto antrópico, resistência antimicrobiana.

\section{INTRODUCTION}

Wastes arising from human activities are rich in recalcitrant compounds such as antimicrobials, metals and biocides, which can reach water bodies and contribute significantly to the selection of resistant bacteria phenotypes (Petit et al., 2014). Although water courses seem to play a key role in the maintenance of resistance phenotypes in nature, little attention has been paid to the influence of human activities on the prevalence of resistance in these resources (Pruden et al., 2012; Czekalski et al., 2015; Yang et al., 2017).

Bacteria can be intrinsically resistant to chemicals or acquire resistance determinants via DNA mutations, transformation by foreign DNA incorporation or phage-mediated transduction, or by conjugation (Blair et al., 2015). Antimicrobial-resistant bacteria represent a severe public health problem on a global scale. This has been studied from the clinical perspective over time but the aquatic environment has also been source of resistance determinants with clinical relevance, e. g. bla $a_{\mathrm{GES}-5}$ gene - a carbapenem resistance determinant found in different species

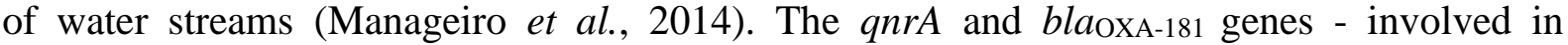
resistance to quinolones and carbapenems, were found in Shewanella algae from marine water samples and in Shewanella xiamenensis from swabs of seepage water, respectively (Poirel et al., 2005; Potron et al., 2011).

Around $39 \%$ of the global population lives less than $100 \mathrm{~km}$ from the coastline (Kummu et al., 2016). Some beaches from southern Brazil attract many travellers, particularly during the summer (from December to February), when populations from some seaside locations increase up to five times (Zuanazzi and Bartels, 2016). The area of Tramandaí Hydrographic River Basin, e. g., has a population of 220,296 inhabitants; however, it can reach up to 580,000 inhabitants during summer (Rio Grande do Sul, 2017). This area is composed of a set of many coastal lagoons which flow into the Tramandaí Lagoon before flowing to the Atlantic Ocean. 
The increased human activities along the coastal might directly imply in waste overproduction, raising the risk of exposure the water resources to pollutant inputs, which constitutes a premise for constant environmental monitoring.

Levels of antimicrobial contamination have already been detected in water bodies of Brazil (Quadra et al., 2017), but bacterial resistance has been poorly studied in these environments (Nascimento and Araújo, 2014; da Costa Andrade et al., 2015; Monteiro et al., 2016; Oliveira et al., 2016). In this way, this study aims to evaluate the presence of antibiotic resistant bacteria (ARB) in surface waters of Tramandaí Lagoon and whether it varies according to the presence of different anthropic disturbances. For this purpose, water samples were characterized for physicochemical and biological variables, the resistance to the antimicrobial classes quinolone, cephalosporin, carbapenem and tetracycline and presence of antibiotic resistance genes (ARGs) by conventional PCR. The study was designed to infer whether the presence of resistant bacteria in the Lagoon may vary according to 1) the presence of antibiotic residues in the environment, 2) human activities present in loco, and 3) increase in local population during peak season.

\section{MATERIAL AND METHODS}

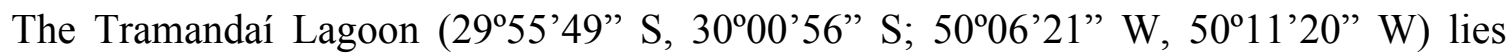
between the Tramandaí and Imbé cities, on the Northern coastal region of Rio Grande do Sul, Southern Brazil (Figure 1). The Lagoon has about $18.8 \mathrm{~km}^{2}$ of area with $1.4 \mathrm{~m}$ of maximum depth, presenting an estuarine channel with a length of $1.5 \mathrm{~km}$, maximum width of $300 \mathrm{~m}$ and maximum depth of $5 \mathrm{~m}$. This estuary is responsible for draining to waters from Tramandaí Hydrographic Basin into the Atlantic Ocean (Figure 1B), a system which occupies an area of approximately $2700 \mathrm{~km}^{2}$ and supplies water to 17 different cities. The Tramandaí Lagoon water uses include irrigation of rice crops areas (mainly from November to February), recreational activities, public supply and the dilution of domestic and industrial wastes, particularly near urban areas (Loitzenbauer and Mendes, 2012). Fishing and tourism are the main regional economic activities.

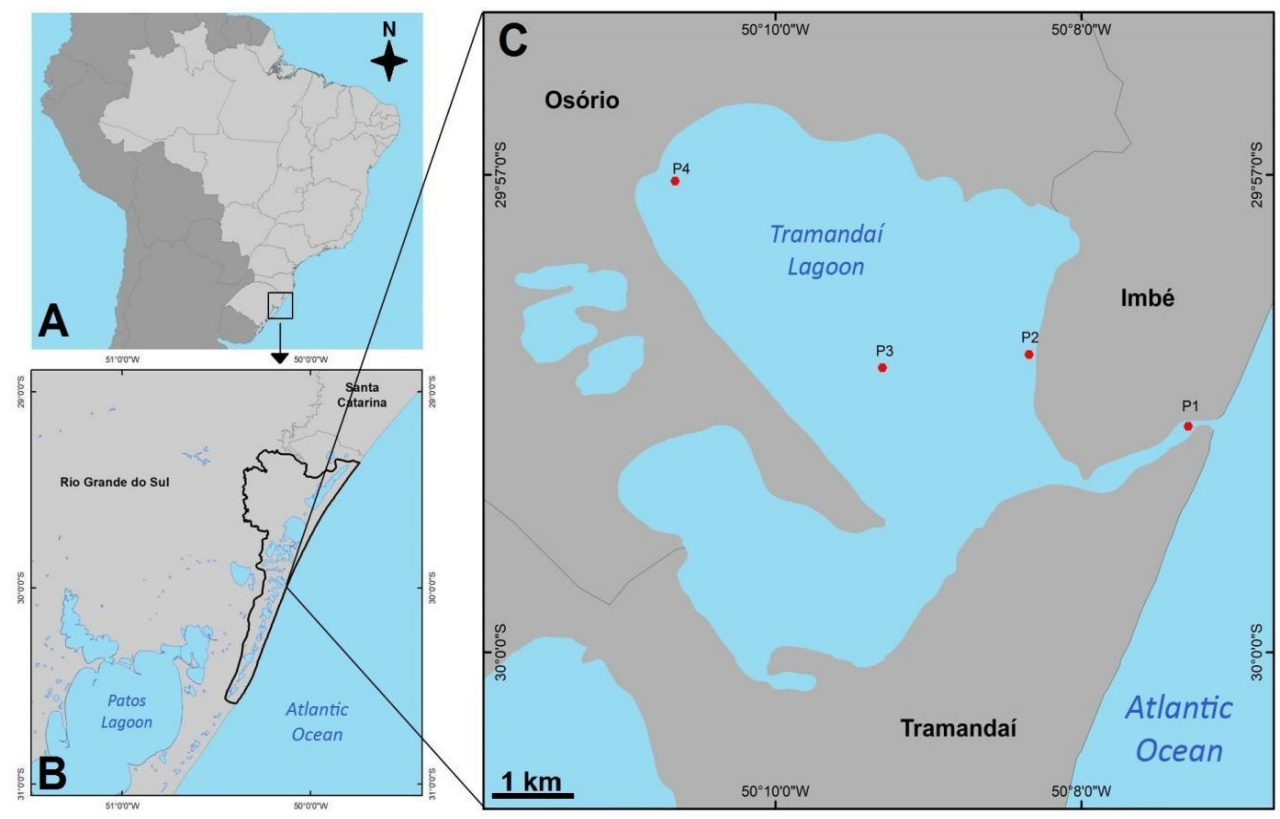

Figure 1. Study site. (A) Rio Grande do Sul state in Southern Brazil. (B) Tramandaí Hydrographic River Basin in Rio Grande do Sul. (C) Tramandaí Lagoon position and the sampling points (P1: Point 1; P2: Point 2; P3: Point 3; P4: Point 4). At the south is Tramandaí city and at the north is Imbé city. 
The surrounding beaches are classified as intermediate and dissipative, being dominated by waves of $1.5 \mathrm{~m}$ on average. They are governed by a micro-tidal regime; the astronomical tide in this area has annual average amplitude of $0.47 \mathrm{~m}$. South storms induce meteorological tides that can reach $1.3 \mathrm{~m}$, significantly amplifying the erosion effects over the shoreline (Calliari et al., 2009). Tidal oscillation causes the ingression of marine waters by the estuarine channel, salinising not only portions of the Tramandaí Lagoon, but also distant water bodies. Ocean water circulation patterns are driven by the confluence of Tropical Waters - transported by Brazilian Current, with a North-South direction and higher prevalence in the summer, and Subtropical and Subantarctic Waters - transported by Malvinas Current, with South-North direction and higher intensity in winter. Northeast and east winds are prevalent. The annual average is about $1000-1200 \mathrm{~mm}$ of precipitation and surface water temperature of $18^{\circ} \mathrm{C}\left(24.6^{\circ} \mathrm{C}\right.$ in January and $13.1^{\circ} \mathrm{C}$ in July) (Medeanic, 2006).

Since the population varies considerably among the seasons in the study area, samples were collected in two samplings, one in the "low season" (August 2014) and another one in the "peak season" (January 2015). The sampling points were selected according the different anthropogenic pressures acting on the environment. The location of points is shown in Figure 1C, while their respective landscapes are illustrated in Figure 1. Point 1 (29 58'34.7" S; $50^{\circ} 07^{\prime} 18.8^{\prime \prime} \mathrm{W}$ ) (Figure 1C), the closest one to the sea, is marked by accentuated urbanization (Figure 2A) and presents a maritime terminal for oil exploration (Almirante Dutra Maritime Terminal) (Figure 2B). Point 2 (29 58'10.4" S; 5008'20.7" W) (Figure 1C) is in a densely urbanized zone, adjoining the exit of a residential horizontal condominium at Imbé city (Figures $2 \mathrm{C}$ and 2D). It is most protected from the marine currents, located closest to a connection with Tramandaí River, by which water flows from other locations in the Basin enter the Tramandaí Lagoon. Point 3 (29 $9^{\circ} 8^{\prime} 12.2^{\prime \prime}$ S; 50 $09^{\prime} 19.7^{\prime \prime} \mathrm{W}$ ) (Figure 1C) is sited at the center of the lagoon, representing the waters confluence of the whole Lagoon (Figure 2E). Point 4 (29 $57^{\prime} 05.8 \mathrm{~S}$, $50^{\circ} 10^{\prime} 41.7^{\prime \prime} \mathrm{W}$ ) (Figure 1C) is not urbanized, and is surrounded by a native forest (Figure 2F) with nearby rice fields. These points were reached with the assistance of a small watercraft. Samples of surface water (less than $1 \mathrm{~m}$ deep) were collected with sterile flasks (capacity of two liters) and kept at $4^{\circ} \mathrm{C}$.

The water samples were characterized for the following physicochemical variables: temperature, turbidity (by Secchi disk, in the collecting), salinity (by electric conductivity), total solid particles (by gravimetric method), dissolved oxygen (by Winkler method), total nitrogen (by colorimetric method), ammoniacal nitrogen (by Nessler method) and total phosphorus, nitrate, nitrite (both by ion chromatography). Total heterotrophic counts were determined by serial dilution directly from the water samples, followed by spread plate cultivation of $0.1 \mathrm{ml}$ in PCA media (Plate Counting Agar) (incubation at $35^{\circ} \mathrm{C}$, until $72 \mathrm{~h}$ ). Total and thermotolerant coliform counts were determined by membrane filtering method: aliquots of water $(100 \mathrm{~mL})$ were filtered through nitrocellulose membranes $(0.2 \mu \mathrm{m}$ porosity), which were subsequently deposited on plates containing LES-ENDO Agar. Colonies were counted after $24 \mathrm{~h}$ of incubation at $35^{\circ} \mathrm{C}$ for total coliforms and $45^{\circ} \mathrm{C}$ for thermotolerant coliforms.

The presence of antimicrobials was analyzed on samples according to Jank et al. (2014) (technique able to detect residues in concentration above $400 \mathrm{ng} . \mathrm{L}^{-1}$ in water). Forty-five types of antimicrobials, from eight different classes, were investigated in samples: sulphadoxazole, sulphadiazine, sulphaclorpyridazine, sulphadoxine, sulphadimetoxin, sulphisoxazole and sulphamethoxazole (sulphonamides); tetracycline, oxytetracycline, chlortetracycline and doxycycline (tetracyclines); norfloxacin, sarafloxacin, difloxacin, danofloxacin, ciprofloxacin, enrofloxacin, norfloxacin, nalidixic acid and flumequine (quinolones); trimethoprim (pyrimidines); penicillin G, ampicillin, cloxacillin, oxacillin and dicloxacillin (penicillins); cephalexin, cephapirin, cephalone, ceftiofur, cephoperazone, cefquinome (cephalosporins); 
lincomycin (lincosamines); erythromycin, azithromycin, tylosin, clindamycin, tilmicosin, spiramycin and nafcillin (macrolides). Additionally, 171 organic compounds (pesticides) were monitored on samples by the qualitative analytical methodology (Diaz et al., 2013). Both these analyses were carried using equipment from the National Agricultural Laboratory (LANAGRO): a liquid chromatography 1100 Series (Agilent Technologies) coupled to a tandem triple quadrupole mass spectrometer API 5000 (Applied Biosystems) using an electrospray probe (ESI) in positive mode as an ionisation source.

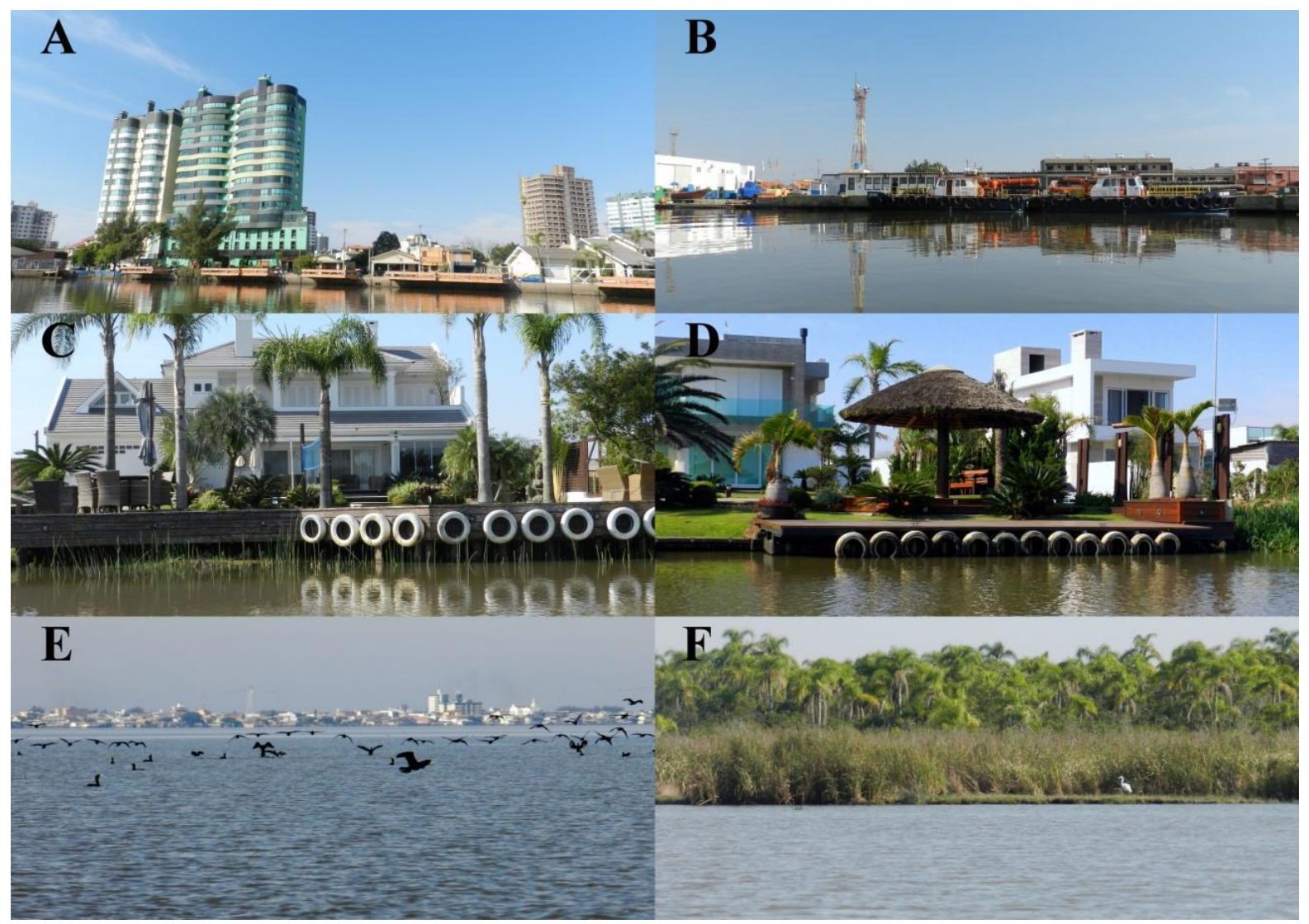

Figure 2. Different landscapes from sampling points. (A) Buildings surrounding Point 1. (B) Maritime terminal for oil exploration next to Point 1. (C) (D) Houses from residential condominium adjacent to Point 2. (E) Landscape from Point 3, in the center of Tramandaí Lagoon. Densely urbanized margins are represented in the background. (F) Native forest in Point 4, where there are no buildings.

The water samples were concentrated by filtration through membranes with $0.2 \mu \mathrm{m}$ of porosity and the total DNA was extracted by UltraClean Soil DNA Kit (MoBio Laboratories, Inc.), according to manufacturer's instructions. The DNA was quantified using Quantus Fluorometer (Promega) with the Quantifluor DNA System kit (Promega) according to manufacturer's recommendations. The presence of antimicrobial resistance genes was assessed

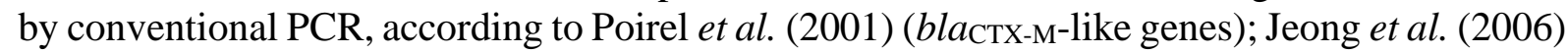
(bla $a_{\mathrm{GES}}$-like genes); Woodford et al. (2006) (bla $a_{\mathrm{OXA}-51}$, bla $_{\mathrm{OXA}-23-l i k e}$ genes); Talukdar et al.

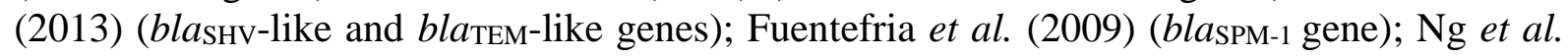
(2001) (tetA and tetB); Lévesque et al. (1995) (Class I integron using primers to the 5' and 3' conserved segments); Swick et al. (2011) (acrA, acrB and tolC); Beheshti et al. (2014) (adeA, ade $\mathrm{B}$, ade $\mathrm{R}$ and adeS); Yoneda et al. (2005) (mexB and mexY); Xavier et al. (2010) (mexD) and Oh et al. (2003) (mexF). Positive controls of the genes were included in all reactions. The primers and PCR conditions are listed in Supplemental material S1. The amplifications were performed with 10ng of genomic DNA in a final volume of $25 \mu \mathrm{L}$. The primers were able to amplify from $2 \mathrm{ng}$ to $0.01 \mathrm{ng}$ of control DNA. Amplification of the 16SrRNA gene was 
performed for all the DNA samples, to ensure the negative result.

Antibiotic resistant bacterial populations from Tramandaí Lagoon waters samples were determined by counts of colony-forming units able to growth in the presence of nalidixic acid, ceftazidime, imipenem and tetracycline in a final concentration of $20 \mathrm{mg} . \mathrm{L}^{-1}$ (chosen according to MIC breakpoints) (CLSI, 2014). Water samples were cultured with nutrient broth (volume $1: 1$, by $24 \mathrm{~h}$ to $35^{\circ} \mathrm{C}$ ) with antibiotic supplementation and after were grown in Plate Counting Agar (PCA) also supplemented with the corresponding antibiotic $\left(24 \mathrm{~h}\right.$ at $\left.35^{\circ} \mathrm{C}\right)$. Control samples for all sites were grown in nutrient broth and PCA without antibiotic supplementation.

All bacterial counts (total heterotrophic, total and thermotolerant coliforms and antibiotic resistant) were reported as $\log _{10}$-transformed counts and weighted by analysis of variance (ANOVA). Tukey's post hoc test was applied to compare the data between seasons and lagoon points. Dunnett's post hoc test was used to compare the data of different antimicrobial treatments with the control. Statistical significance was assigned to $\mathrm{P}<0.05$. Correlations between the environmental variables, microbiological variables and resistant bacteria counts were appraised by Pearson's correlation coefficient. A multivariate statistical projection method (Principal Component Analysis - PCA) was also applied to reduce the dimensionality and analyze the data.

\section{RESULTS AND DISCUSSION}

Tramandaí Lagoon was under the ebbing tide in "low season" sampling, while in "peak season" it was under the flooding tide. Although the lagoon is a highly dynamic environment, the environmental variables assessed allow inferences about the in situ conditions at sampling time. The tide seems to have influenced especially the higher total solids content and the lower salinity and visibility values in "low season" (Table 1), since river inflows can reduce the salinity and carry particles arising from upstream erosion processes in addition to resuspending the bottom sediment.

Independent of the season and tide, the Points 1 and 2 showed some characteristics attributed to greater urbanization, like higher nutrient concentrations (nitrate was detectable just in Point 2) and higher bacterial counts, especially for thermotolerant coliforms (Table 1). Under acceptable conditions by the Brazilian government environmental law (CONAMA Resolution $\left.\mathrm{n}^{\circ} 357\right)$ (CONAMA, 2005), natural brackish waters have levels of phosphorus below $0.124 \mathrm{mg} . \mathrm{L}^{-1}$ and ammoniacal nitrogen below $0.40 \mathrm{mg} . \mathrm{L}-1$, higher values indicate environmental imbalance in the lagoon at points marked by urbanization. Therefore, the human activities impact present in the Points 1 and 2 might represent a punctual disturbance, even in the periods of population decline ("low season"). On the other hand, Points 3 and 4, not urbanized, generally exhibited the lower nutrient levels and the higher values for oxygen dissolved and visibility (Table 1).

The total heterotrophic counts in Point 3 differed between samplings (Table 1), probably influenced by the position in the center of the lagoon and by inputs of nutrient-enriched waters due to the river ebbing. Point 3 has also shown the lower thermotolerant coliforms counts in the "low season" (Table 1), which can be connected to a lower punctual impact or even to the dilution of faecal pollution. Point 2 was the only point where all microbiological variables varied among the seasons (Table 1). Though has presented the highest thermotolerant coliforms counts in both seasons (Table 1), this point was more affected by faecal pollution in the "peak season".

Despite the anthropogenic activities observed locally, antibiotic residues were not observed in water samples at any season or point from Tramandaí Lagoon, which does not exclude the possibility of contamination in lower levels than the limit of detection (400ng. $\mathrm{L}^{-1}$ ). Antibiotics rarely occur in lethal concentrations outside clinical environments, 
mainly in highly diluted environments such as water courses (Kummerer, 2009). Even though, resistant bacteria were present in Tramandaí Lagoon samples in both seasons, in almost all points and for almost all antibiotic treatments tested (Table 2). Therefore, low antibiotic concentrations can also contribute to the selection of resistance in wild-type susceptible populations (Gullberg et al., 2011).

Table 1. Characterization of Lagoon samples to physicochemical and microbiological variables, in "low" and "peak" seasons (respectively on August 2014 and January 2015).

\begin{tabular}{|c|c|c|c|c|c|}
\hline Variables & Seasons & Point 1 & Point 2 & Point 3 & Point 4 \\
\hline \multirow{2}{*}{ Temperature $\left({ }^{\circ} \mathrm{C}\right)$} & Low & 15.7 & 16.2 & 15.5 & 17.2 \\
\hline & Peak & 24.8 & 26.5 & 24.6 & 25.1 \\
\hline \multirow{2}{*}{ Salinity (ppt) } & Low & 9.22 & 0.1 & 10.05 & 12.11 \\
\hline & Peak & 64.98 & 31.42 & 22.36 & 11.97 \\
\hline \multirow{2}{*}{$\begin{array}{l}\text { Dissolved oxygen }\left(\mathrm{O}_{2}\right) \\
\left(\mathrm{mg} \cdot \mathrm{L}^{-1}\right)\end{array}$} & Low & 10.32 & 9.16 & 9.99 & 10.44 \\
\hline & Peak & 7.9 & 7.5 & 7.3 & 7.1 \\
\hline \multirow{2}{*}{$\begin{array}{l}\text { Total phosphorus }(\mathrm{P}) \\
\left(\mathrm{mg} \cdot \mathrm{L}^{-1}\right)\end{array}$} & Low & 0.08 & 0.12 & 0.06 & 0.06 \\
\hline & Peak & 0.08 & 0.07 & 0.07 & 0.06 \\
\hline \multirow{2}{*}{$\begin{array}{l}\text { Total nitrogen }(\mathrm{N}) \\
\left(\mathrm{mg} \cdot \mathrm{L}^{-1}\right)\end{array}$} & Low & 5.3 & 3.99 & 1.37 & 1.44 \\
\hline & Peak & 2.08 & 9.63 & 2.6 & 2.08 \\
\hline \multirow{2}{*}{$\begin{array}{l}\text { Nitrite }\left(\mathrm{NO}_{2}\right) \\
\left(\mathrm{mg} \cdot \mathrm{L}^{-1}\right)\end{array}$} & Low & ND & 1,02 & ND & ND \\
\hline & Peak & ND & ND & ND & ND \\
\hline \multirow{2}{*}{$\begin{array}{l}\text { Nitrate }\left(\mathrm{NO}_{3}\right) \\
\left(\mathrm{mg} \cdot \mathrm{L}^{-1}\right)\end{array}$} & Low & ND & ND & ND & ND \\
\hline & Peak & ND & ND & ND & ND \\
\hline \multirow{2}{*}{$\begin{array}{l}\text { Ammoniacal nitrogen } \\
\left(\mathrm{NH}_{4}\right)\left(\mathrm{mg} . \mathrm{L}^{-1}\right)\end{array}$} & Low & 4.3 & 3.7 & 0.07 & 0.16 \\
\hline & Peak & 0.78 & 2.34 & 2.21 & 1.56 \\
\hline \multirow{2}{*}{$\begin{array}{l}\text { Total solids } \\
\left(\mathrm{mg} \cdot \mathrm{L}^{-1}\right)\end{array}$} & Low & 5018 & 122 & 5548 & 6319 \\
\hline & Peak & 37.99 & 17.69 & 13.03 & 6.98 \\
\hline \multirow{2}{*}{ Visibility $(\mathrm{cm})$} & Low & 50 & 40 & 40 & 70 \\
\hline & Peak & 60 & 60 & 80 & 60 \\
\hline \multirow{2}{*}{$\begin{array}{l}\text { Total heterotrophic } \\
\text { (mean CFU count }+\mathrm{SD})\end{array}$} & Low & $3.74 \pm 0.17^{\mathrm{A}}$ & $2.73 \pm 0.46^{\mathrm{A}, \mathrm{C}}$ & $4.37 \pm 0.05^{\mathrm{A}, \mathrm{B}}$ & $2.91 \pm 0.44^{\mathrm{A}, \mathrm{C}}$ \\
\hline & Peak & $2.82 \pm 1.04^{\mathrm{B}}$ & $4.45 \pm 0.25^{\mathrm{A}}$ & $2.25 \pm 0.24^{\mathrm{B}, \mathrm{C}}$ & $3.49 \pm 0.88^{\mathrm{A}, \mathrm{B}, \mathrm{C}}$ \\
\hline \multirow{2}{*}{$\begin{array}{l}\text { Total coliforms } \\
(\text { mean CFU count }+\mathrm{SD})\end{array}$} & Low & $3 \pm 0.14 \mathrm{~A}$ & $2.4 \pm 0.46^{\mathrm{A}}$ & $3.02 \pm 0.04^{\mathrm{A}}$ & $3.03 \pm 0.48^{\mathrm{A}}$ \\
\hline & Peak & $2.45 \pm 0.59^{\mathrm{B}}$ & $4.29 \pm 0.25^{\mathrm{A}}$ & $2.43 \pm 0.1^{\mathrm{B}}$ & $2.4 \pm 0.1^{\mathrm{B}}$ \\
\hline \multirow{2}{*}{$\begin{array}{l}\text { Thermotolerant coliforms } \\
\text { (mean CFU count }+\mathrm{SD})\end{array}$} & Low & $2.47 \pm 0.45^{\mathrm{A}}$ & $2.5 \pm 0.24^{A}$ & $2 \pm 0.1^{\mathrm{B}}$ & $2.64 \pm 0.19^{A}$ \\
\hline & Peak & $0.88 \pm 0.32^{\mathrm{C}}$ & $4.24 \pm 0.21^{A}$ & $1.84 \pm 0.25^{\mathrm{B}}$ & $1.44 \pm 0.18^{\mathrm{B}, \mathrm{C}}$ \\
\hline
\end{tabular}

ppt: parts per thousand. ND: not detected. Limits of detection: nitrate $\left(0.03 \mathrm{mg} . \mathrm{L}^{-1}\right)$, nitrite $\left(0.04 \mathrm{mg} . \mathrm{L}^{-1}\right)$. Counts were expressed in colony-forming unit mean \pm standard deviation (log 10 -transformed). Significantly different values are bold marked (seasons comparison) or present different letters (points comparison) ( $p<0.05$, Two-way ANOVA followed by Tukey's post hoc test). 
Table 2. Characterization of Lagoon water samples according to the presence of resistance genes in the DNA samples and total counts of resistant bacteria after growth in the presence of antibiotic, in "low" and "peak" seasons (respectively, on August 2014 and January 2015).

\begin{tabular}{|c|c|c|c|c|c|}
\hline & Season & Point 1 & Point 2 & Point 3 & Point 4 \\
\hline \multirow{2}{*}{$\begin{array}{l}\text { Resistance genes } \\
\text { amplified }\end{array}$} & Low & $\begin{array}{l}\text { Class I integron, bla } a_{\mathrm{GES}}, a c r \mathrm{~A} \text {, } \\
\text { acr } \mathrm{B}, \text { tol } \mathrm{C}, \text { mex } \mathrm{B}, \text { mex } \mathrm{F} \text {. }\end{array}$ & $\begin{array}{l}\text { bla }{ }_{\mathrm{GES}}, \text { tet } \mathrm{B}, \operatorname{acr} \mathrm{A}, \operatorname{acr} \mathrm{B}, \\
\text { ades, mex } \mathrm{B}, \text { mex } \mathrm{F} .\end{array}$ & Class I integron. & bla $_{\mathrm{GES}}$, acrB, tolC. \\
\hline & Peak & 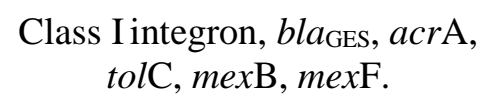 & $\begin{array}{l}\text { Class I integron, bla }{ }_{\mathrm{GES}} \\
\text { adeS, mex } \mathrm{B}, \text { mex } \mathrm{F} \text {. }\end{array}$ & $\begin{array}{l}\text { Class I integron, bla } a_{\mathrm{GES}}, \\
\text { acr } \mathrm{A}, \text { acrB, tolC, mex } \mathrm{B} .\end{array}$ & $\begin{array}{c}\text { Class I integron, bla } a_{\mathrm{GES}}, a c r \mathrm{~A}, \\
\text { acr } \mathrm{B}, \text { ade } \mathrm{S}, \text { mex } \mathrm{B}, \text { mex } \mathrm{F} \text {. }\end{array}$ \\
\hline \multirow{2}{*}{ Control } & Low & $>14^{A}$ & $>14^{\mathrm{A}}$ & $>14^{\mathrm{A}}$ & $>14^{\mathrm{A}}$ \\
\hline & Peak & $5.52 \pm 0.10^{\text {B }}$ & $11.61 \pm 1.91^{\mathrm{A}}$ & $11.79 \pm 1.90^{\mathrm{A}}$ & $>14^{\mathrm{A}}$ \\
\hline \multirow{2}{*}{$\begin{array}{l}\text { Nalidixic acid } \\
\text { treatment }\end{array}$} & Low & $7.56 \pm 0.02^{B}$ & $8.00 \pm 1.36^{\text {в }}$ & $>14^{\mathrm{A} *}$ & $>14^{\mathrm{A} *}$ \\
\hline & Peak & $>14^{\mathrm{A} * *}$ & $11.21 \pm 2.28 \mathrm{~A} *$ & $9.32 \pm 0.07$ B $*$ & $13.41 \pm 0.51 \mathrm{~A} *$ \\
\hline \multirow{2}{*}{$\begin{array}{l}\text { Ceftazidime } \\
\text { treatment }\end{array}$} & Low & $8.43 \pm 0.71^{B}$ & $9.71 \pm 0.03^{\text {в }}$ & $1.02 \pm 0.011^{C}$ & $>14^{A}$ \\
\hline & Peak & $5.11 \pm 0.14^{\mathrm{B} *}$ & $9.49 \pm 2.27 \mathrm{~A} *$ & $4.84 \pm 0.21^{B}$ & $5.41 \pm 0.18{ }^{A B}$ \\
\hline \multirow{2}{*}{$\begin{array}{l}\text { Imipenem } \\
\text { treatment }\end{array}$} & Low & $10.09 \pm 0.03^{\text {B }}$ & $9.79 \pm 0.05^{\text {в }}$ & $8.93 \pm 1.12^{\text {в }}$ & $>14^{A}$ \\
\hline & Peak & ND & $7.73 \pm 4.21^{\mathrm{A}}$ & $3.13 \pm 1.02^{\mathrm{B}}$ & $2.72 \pm 0.33^{B}$ \\
\hline \multirow{2}{*}{$\begin{array}{l}\text { Tetracycline } \\
\text { treatment }\end{array}$} & Low & $13.02 \pm 2.53^{\mathrm{A} *}$ & $>14^{\mathrm{A} *}$ & $8.93 \pm 1.12^{\text {в }}$ & $>14^{\mathrm{A} *}$ \\
\hline & Peak & $11.24 \pm 1.86^{\mathrm{A} * *}$ & $12.86 \pm 0.02 \mathrm{~A} * *$ & $8.66 \pm 0.45 \mathrm{~A} *$ & $2.3 \pm 0.01^{B}$ \\
\hline
\end{tabular}

Bacterial counts expressed as Colony-forming unit mean \pm standard deviation (values $\log _{10}$-transformed).

Significantly different values are bold marked (seasons comparison) or present different letters (points comparison in the same season) ( $p<0.05$, Two-way ANOVA followed by Tukey's post hoc test).

* Resistant bacteria count is equivalent to control bacteria count ( $p>0.05$, Two-way ANOVA followed by Dunnett's post hoc test). ** Resistant bacteria quantity higher than those present in control.

ND: not detected. 
Comparing the colony-forming unit counts, those from Points 2 and 4 highlighted by the higher scores in both seasons and for almost all types of antimicrobial supplementation (Table 2). Counts from controls samples refers to total cultivable bacteria under non selective enrichment and might include both native resistant and sensitive bacteria. Then, ARB counts from samples with antimicrobials which were equivalent to the respective control counts (values marked with * in Table 2) attracted attention. Although the counts were usually higher in the "low season", counts equivalent to controls were observed in $56.25 \%$ of samples $(9 / 16)$ in the "peak season", when anthropogenic activities have increased in the region (Table 2). Additionally, Point 2 was the only one in which the ARB counts did not vary between seasons (Table 2), reinforcing the likely influence of local factors to antibiotic resistance maintenance.

Nalidixic acid and tetracycline selected higher counts of ARB than ceftazidime and imipenem (Table 2). The tetracycline was the only antimicrobial evaluated which has a biological origin. Hatosy and Martiny (2015) drew attention to the fact of the resistance to synthetic antimicrobials can be a result of contaminated effluents, since microbes would not experience these molecules in natural microbe-microbe interactions. Then, the prevalence of nalidixic acid resistant bacteria might be a reflection of local anthropic disturbances. Higher counts of nalidixic acid resistance were observed at Points 3 and 4 in low season and at Point 1 in peak season (Table 2). This shows that even the microbiota from non-urbanized regions (Points 3 and 4) can be impacted for antimicrobial resistance, which has already been reported around the world (Bhullar et al., 2012; Chen et al., 2013).

The increase in tetracycline resistance on water courses has also been attributed to the possible overuse in aquaculture (Young et al., 2013) or agriculture (Winkworth-Lawrence and Lange, 2016). A large part of the Tramandaí River Basin area is composed of crops (Loitzenbauer and Mendes, 2012) which probably impact the adjoining waters. Waters from Point 4, next to rice crop areas, revealed high resistant counts in the "low season". These results suggest that the agriculture management seemed to impact the ARB as well as the presence of urbanization, and that the "low season" represents a period that is as critical to the resistance expression as the "peak season". Residues of Tiamethoxan, Triciclazole and Propoxur (out of the 171 pesticides evaluated) were detected in all sampling sites, probably due to influence of the cropping areas nearby Point 4 . Triciclazole is a broad spectrum fungicide used to control plant diseases in cereals and fruits. Tiametoxan is a neoticotinoid and Propoxur is a carbamate, both groups of drugs are used to control agricultural pests, acting on the central nervous system of insects. Albeit the action on bacterial cells of the pesticides found is unknown, it is a consensus that metals as well as organic compounds can influence the antibiotic resistance genomic display of bacteria (Pal et al., 2017).

The ceftazidime and imipenem resistant populations seemed more sensitive to seasonal variation (different values among seasons are bold marked in Table 2). Even though these populations have been less represented, the selection of imipenem and ceftazidime antimicrobial resistances has been rarely documented in natural environments (Kittinger et al., 2016). The low prevalence of imipenem-resistant bacteria (Table 2) corroborates with previous reports (Montezzi et al., 2015; Malik et al., 2015). The imipenem resistance could probably be related with the presence of blaGES gene on samples - the only bla gene found in Tramandaí Lagoon waters (Table 2). The carbapenemase blaGES-5 has been commonly reported in aquatic isolates of Enterobacteriaceae, considered ubiquitous bacteria in these environments (Manageiro et al., 2014). This gene has also been detected in isolates of Klebsiella sp. and Enterobacter sp. in recreational waters (Paschoal et al., 2017) and aquatic environments (de Araújo et al., 2016).

The Class I integron amplification observed in both groups of samples has been associated with water sources under anthropic impact (Abella et al., 2015; Gillings et al., 2015) and its importance in the assembly of ARGs cassettes and its maintenance in the environment has been 
consistently demonstrated (Stalder et al., 2012). The tetracycline resistance is commonly disseminated in aquatic environments (Harnisz et al., 2015), but despite this we have detected this phenotype throughout the Lagoon area; the tet $\mathrm{B}$ gene was identified only in the low season, at Point 2. Although the genes of the Mex and AcrAB-TolC systems are constitutively expressed, their overexpression has been associated with resistance to fluoroquinolones and carbapenems in isolates of clinical origin (Neves et al., 2011; Singh et al., 2012). In aquatic ecosystems, these efflux pump genes may be associated with distinct resistant phenotypes, mainly to organic molecules (the earlier mentioned pesticides) and metals. Because antibiotics can also be a substrate for them, they also have an important role in the maintenance of resistance phenotypes in oligotrophic environments.

The clustering of resistant counts (including the respective controls) with environmental and microbiological characters by the principal component analysis (PCA) showed some relevant correlations (Figure 3). The variation observed was better explained in the low season (81.33\% of the variability) than in the peak season (76.92\% of the variability) (Figure 3$)$. Since the counts were grouped by the sampling points, the environmental conditions of the points seemed to be more important to assess the total resistance in the cultivable bacteria from the Lagoon than the selective pressure of the antimicrobial class used in the in vitro experiment (Figure 3 ). In the low season, the resistant counts at Point 1 were related to the same variables from Points 2 and 3, which did not present similar interactions with each other (Figure 3). Point 4 counts were weakly correlated with those from other sampling points (Figure 3), evidencing the effect of environmental conditioners in this point. On the other hand, in the peak season, the resistant counts from non-urbanized points ( 3 and 4 ) were strongly correlated with each other, while those from the urbanized points (1 and 2) were weakly correlated and influenced by different variables (Figure 3). In both seasons, the resistant counts from Point 2 were explained by some of the nutrients analyzed as well as by the thermotolerant coliform amounts (whose correlation is even higher in peak season) (Figure 3). Thus, the ARB count variance in this point appeared to be influenced by faecal pollution, especially in the peak season, as a possible effect of the intense anthropogenic activities observed in this period. Landscape changes as a consequence of urbanization have been associated to impact on bacterial communities modifications, including the increasing in both thermotolerant coliforms (Garbossa et al., 2017; Oliveira et al., 2016) and ARB abundance (Wang et al., 2016; Yang et al., 2017).

The quantification of ARB on culture medium supplemented with antimicrobials usually supports studies focused on resistance analysis in water bodies around the world (Harnisz et al., 2015; Mao et al., 2015). However, antimicrobial resistance has been notoriously underestimated in aquatic environments, since both microbial cells and nutrients are highly diluted (Xu et al., 2016). Although present limitations (such as considering just the cultivable fraction of populations, estimating resistance indirectly, not distinguishing between intrinsic and acquired resistance mechanisms or not appraising the variation of ecological attributes like diversity or richness), this approach is a low-cost alternative which allows the resistance in nature to be assessed, even under little environmental representativeness (for example, the ceftazidime and imipenem resistance).

Brazilian studies involving antimicrobial resistance in water sources have focused on freshwater systems, mainly in aquaculture, being based on the disk diffusion technique (Nascimento and Araújo, 2014). This indicates a demand for additional studies on natural and saline environments. The methodology adopted in this paper allows inferences about the resistance in nature, contributing to reduce the analysis time and costs associated with the isolation of pure cultures or antibiotic disks. Antimicrobial resistance has been poorly prospected in water reservoirs from the Brazilian south coast. As estuaries are highly dynamic and complex, evaluating the resistance variability using a larger time scale study is essential to prevent, detect or even mitigate possible resistance outbreaks in these environments. 
Low season (axes F1 and F2: $\mathbf{8 1 . 3 3 \% ) ~}$

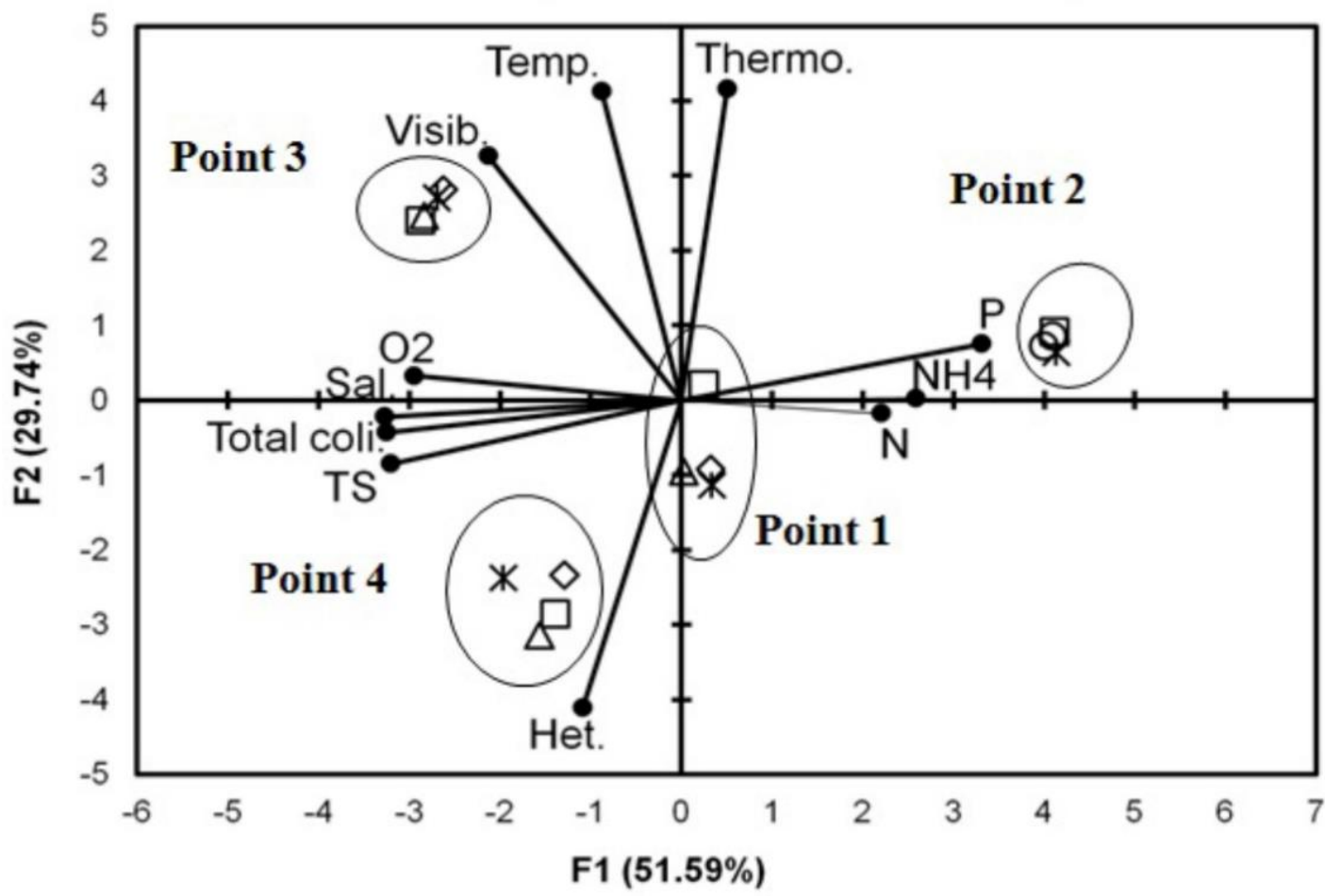

Peak season (axes F1 and F2: $76.92 \%$ )

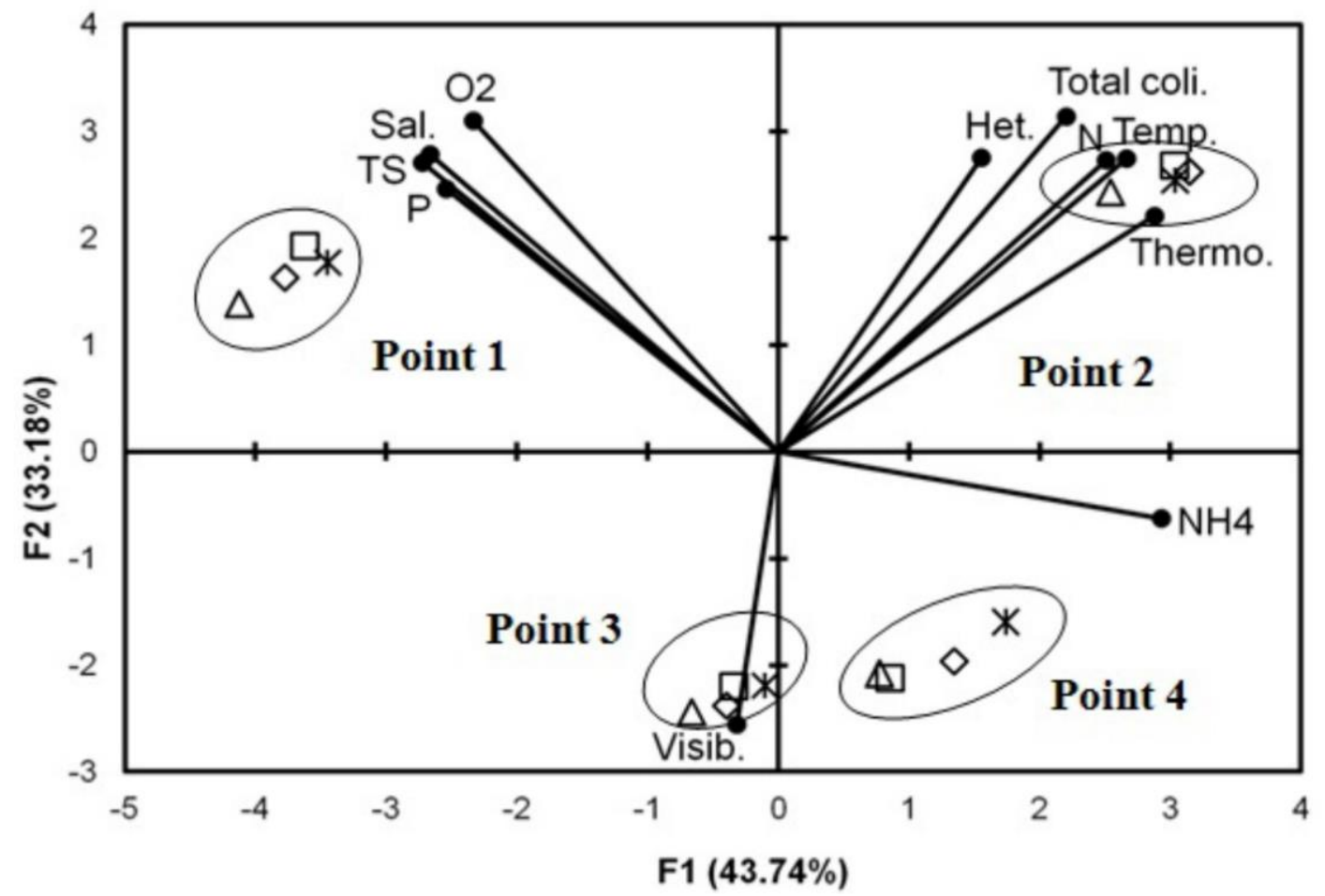

Figure 3. Principal component analysis (PCA) of environment and resistant populations interactions in Tramandaí Lagoon, according to different antimicrobial treatments, sampling points and seasons. $X$ : nalidixic acid treatment. $\square$ : ceftazidime treatment. $\triangle$ : imipenem treatment. $\diamond$ : tetracycline treatment. Temp.: temperature. Sal.: salinity. O2: dissolved oxygen. $P$ : total phosphorus. $N$ : total nitrogen. $N H 4$ : ammoniacal nitrogen. $T S$ : total solids. Visib.: visibility. Het.: total heterotrophic. Total coli: total coliforms. Thermo.: thermotolerant coliforms. 


\section{CONCLUSION}

The present study was able to identify a coastal Lagoon from Southern Brazil as a reservoir of ARGs, even in the absence of detectable antimicrobial molecules. Although the aquatic system assessed has substantial ecological and economic importance for the region, the resistance types detected (especially ceftazidime and imipenem resistance) are clinically relevant in an international overview. Since ARB populations were identified even under low population season, we draw attention to the need to monitor systematically these environments. These insights reinforce the importance of carrying out more studies on natural habitats, in order to identify sources of contamination as well as the response of native bacteria to stresses of anthropogenic origin. Since the coastline zone is worldwide pressured by urbanization, analysis of the impact of human activities on persistent resistance in coastal environments is critical to adopting mitigating actions on a global scale.

\section{ACKNOWLEDGEMENTS}

This study was supported by the Brazilian Federal Government Agency, Coordenação de Aperfeiçoamento de Pessoal de Nível Superior (CAPES).

\section{REFERENCES}

ABELLA, J.; BIELEN, A.; HUANG, L.; DELMONT, T. O.; VUJAKLIJA, D.; DURAN, R.; CAGNON, C. Integron diversity in marine environments. Environmental Science and Pollution Research, v. 22, n. 20, p. 15360-15369, 2015. https://doi.org/10.1007/s11356015-5085-3

BEHESHTI, M.; TALEBI, M.; ARDEBILI, A.; BAHADOR, A.; LARI, A. R. Detection of AdeABC efflux pump genes in tetracycline-resistant Acinetobacter baumannii isolates from burn and ventilator-associated pneumonia patients. Journal of Pharmacy \& Bioallied Sciences, v. 6, n. 4, p. 229, 2014. https://dx.doi.org/10.4103\%2F09757406.142949

BLAIR, J. M.; WEBBER, M. A.; BAYLAY, A. J.; OGBOLU, D. O.; PIDDOCK, L. J. Molecular mechanisms of antibiotic resistance. Nature Reviews Microbiology, v. 13, n. 1, p. 42, 2015.BHULLAR, K. et al. Antibiotic resistance is prevalent in an isolated cave $\begin{array}{llllllll}\text { microbiome. PloS One, v. 7, n. 4, p. } 2012 . & \text { e } 34953,\end{array}$ https://doi.org/10.1371/journal.pone.0034953

CALLIARI, L. J.; WINTERWERP, J. C.; FERNANDES, E.; CUCHIARA, D.; VINZON, S. B.; SPERLE, M.; HOLLAND, K. T. Fine grain sediment transport and deposition in the Patos Lagoon-Cassino beach sedimentary system. Continental Shelf Research, v. 29, n. 3, p. 515-529, 2009. http://doi.org/10.1016/j.csr.2008.09.019

CHEN, B.; YANG, Y.; LIANG, X.; YU, K.; ZHANG, T.; LI, X. Metagenomic profiles of antibiotic resistance genes (ARGs) between human impacted estuary and deep ocean sediments. Environmental Science \& Technology, v. 47, n. 22, p. 12753-12760, 2013. https://doi.org/10.1021/es403818e

CLINICAL AND LABORATORY STANDARDS INSTITUTE (CLSI). Performance standards for antimicrobial susceptibility testing; 24th informational supplement. Wayne, 2014. 
CONAMA (Brasil). Resolução no 357 de 17 de março de 2005. Dispõe sobre a classificação dos corpos de água e diretrizes ambientais para o seu enquadramento, bem como estabelece as condições e padrões de lançamento de efluentes, e dá outras providências. Diário Oficial [da] União: seção 1, Brasília, DF, n. 053, p. 58-63, 18 mar. 2005.

CZEKALSKI, N.; SIGDEL, R.; BIRTEL, J.; MATTHEWS, B.; BÜRGMANN, H. Does human activity impact the natural antibiotic resistance background? Abundance of antibiotic resistance genes in 21 Swiss lakes. Environment International, v. 81, p. 45-55, 2015. https://doi.org/10.1016/j.envint.2015.04.005

DA COSTA ANDRADE, V.; ZAMPIERI, B. D. B.; BALLESTEROS, E. R.; PINTO, A. B.; DE OLIVEIRA, A. J. F. C. Densities and antimicrobial resistance of Escherichia coli isolated from marine waters and beach sands. Environmental Monitoring and Assessment, v. 187, n. 6, p. 342, 2015. https://doi.org/10.1007/s10661-015-4573-8

DE ARAUJO, C. F. M.; SILVA, D. M.; CARNEIRO, M. T.; RIBEIRO, S.; FONTANAMAURELL, M.; ALVAREZ, P.; CARVALHO-ASSEF, A. P. D. A. Detection of carbapenemase genes in aquatic environments in Rio de Janeiro, Brazil. Antimicrobial Agents and Chemotherapy, 2016. https://dx.doi.org/10.1128/AAC.02753-15

DIAZ, R.; IBÁÑEZ, M.; SANCHO, J. V.; HERNÁNDEZ, F. Qualitative validation of a liquid chromatography-quadrupole-time of flight mass spectrometry screening method for organic pollutants in waters. Journal of Chromatography A, v. 1276, p. 47-57, 2013. https://doi.org/10.1016/j.chroma.2012.12.030

FUENTEFRIA, D. B.; FERREIRA, A. E.; GRÄF, T.; CORÇÃO, G. Spread of Metallo- $\beta$ lactamases: screening reveals the presence of a BLA SPM-1 gene in hospital sewage in southern Brazil. Brazilian Journal of Microbiology, v. 40, n. 1, p. 82-85, 2009. http://dx.doi.org/10.1590/S1517-83822009000100013

GARBOSSA, L. H.; SOUZA, R. V.; CAMPOS, C. J.; VANZ, A.; VIANNA, L. F.; RUPP, G. S. Thermotolerant coliform loadings to coastal areas of Santa Catarina (Brazil) evidence the effect of growing urbanisation and insufficient provision of sewerage infrastructure. Environmental Monitoring and Assessment, v. 189, n. 1, p. 27, 2017. https://doi.org/10.1007/s10661-016-5742-0

GILLINGS, M. R.; GAZE, W. H.; PRUDEN, A.; SMALLA, K.; TIEDJE, J. M.; ZHU, Y. G. Using the class 1 integron-integrase gene as a proxy for anthropogenic pollution. The ISME Journal, v. 9, n. 6, p. 1269, 2015.

GULLBERG, E.; CAO, S.; BERG, O. G.; ILBÄCK, C.; SANDEGREN, L.; HUGHES, D.; ANDERSSON, D. I. Selection of resistant bacteria at very low antibiotic concentrations. $\begin{array}{llllllll}\text { PLoS Pathogens, } & \text { v. 7, n. 7, p. }\end{array}$ https://doi.org/10.1371/journal.ppat.1002158

HARNISZ, M.; KORZENIEWSKA, E.; CIESIELSKI, S.; GOŁAŚ, I. tet genes as indicators of changes in the water environment: Relationships between culture-dependent and cultureindependent approaches. Science of the Total Environment, v. 505, p. 704-711, 2015. https://doi.org/10.1016/j.scitotenv.2014.10.048

HATOSY, S. M.; MARTINY, A. C. The ocean as a global reservoir of antibiotic resistance genes. Applied and Environmental Microbiology, 2015. https://dx.doi.org/10.1128/AEM.00736-15 
JANK, L.; HOFF, R. B.; COSTA, F. J. D.; PIZZOLATO, T. M. Simultaneous determination of eight antibiotics from distinct classes in surface and wastewater samples by solid-phase extraction and high-performance liquid chromatography-electrospray ionisation mass spectrometry. International Journal of Environmental Analytical Chemistry, v. 94, n. 10, p. 1013-1037, 2014. https://doi.org/10.1080/03067319.2014.914184

JEONG, S. H.; BAE, I. K.; PARK, K. O.; AN, Y. J.; SOHN, S. G.; JANG, S. J.; LEE, S. H. Outbreaks of imipenem-resistant Acinetobacter baumannii producing carbapenemases in Korea. The Journal of Microbiology, v. 44, n. 4, p. 423-431, 2006.

KUMMU, M.; DE MOEL, H.; SALVUCCI, G.; VIVIROLI, D.; WARD, P. J.; VARIS, O. Over the hills and further away from coast: global geospatial patterns of human and environment over the 20th-21st centuries. Environmental Research Letters, v. 11, n. 3, p. 034010, 2016.

LÉVESQUE, C.; PICHE, L.; LAROSE, C.; ROY, P. H. PCR mapping of integrons reveals several novel combinations of resistance genes. Antimicrobial Agents and Chemotherapy, v. 39, n. 1, p. 185-191, 1995. https://dx.doi.org/10.1128/AAC.39.1.185

KITTINGER, C.; LIPP, M.; BAUMERT, R.; FOLLI, B.; KORAIMANN, G.; TOPLITSCH, D.; ZARFEL, G. Antibiotic resistance patterns of Pseudomonas spp. isolated from the River Danube. Frontiers in Microbiology, v. 7, p. 586, 2016. https://doi.org/10.3389/fmicb.2016.00586

LOITZENBAUER, E.; MENDES, C. A. B. Salinity dynamics as a tool for water resources management in coastal zones: An application in the Tramandaí River basin, southern Brazil. Ocean \& Coastal Management, v. 55, p. 52-62, 2012. https://doi.org/10.1016/j.ocecoaman.2011.10.011

MALIK, A.; KHAN, F.; RIZVI, M.; SHUKLA, I.; AFAQ, S.; SULTAN, A. Trends in Antimicrobial Resistance of Bacterial Isolates Circulating in Sewage Waters of Aligarh Region over a Period of 14 Years. Asian Journal of Water, Environment and Pollution, v. 12, n. 1, p. 69-74, 2015.

MANAGEIRO, V.; FERREIRA, E.; CANIÇA, M.; MANAIA, C. M. GES-5 among the $\beta$ lactamases detected in ubiquitous bacteria isolated from aquatic environment samples. FEMS Microbiology Letters, v. 351, n. 1, p. 64-69, 2014. https://doi.org/10.1111/15746968.12340

MAO, D.; YU, S.; RYSZ, M.; LUO, Y.; YANG, F.; LI, F.; ALVAREZ, P. J. J. Prevalence and proliferation of antibiotic resistance genes in two municipal wastewater treatment plants. Water Research, v. 85, p. 458-466, 2015. https://doi.org/10.1016/j.watres.2015.09.010

MEDEANIC, S. Freshwater algal palynomorph records from Holocene deposits in the coastal plain of Rio Grande do Sul, Brazil. Review of Paleobotany and Palynology, 2006. https://doi.org/10.1016/j.revpalbo.2006.03.012

MONTEIRO, M. A.; SPISSO, B. F.; DOS SANTOS, J. R. M. P.; DA COSTA, R. P.; FERREIRA, R. G., PEREIRA, M. U.; D'AVILA, L. A. Occurrence of antimicrobials in river water samples from rural region of the State of Rio de Janeiro, Brazil. Journal of $\begin{array}{llllll}\text { Environmental Protection, } & \text { v. } & \text { 7, } & \text { p. }\end{array}$ http://dx.doi.org/10.4236/jep.2016.72020 
MONTEZZI, L. F.; CAMPANA, E. H.; CORRÊA, L. L.; JUSTO, L. H.; PASCHOAL, R. P.; DA SILVA, I. L. V. D.; PICÃO, R. C. Occurrence of carbapenemase-producing bacteria in coastal recreational waters. International Journal of Antimicrobial Agents, v. 45, n. 2, p. 174-177, 2015. https://doi.org/10.1016/j.ijantimicag.2014.10.016

NASCIMENTO, E. D. D.; ARAÚJO, M. F. F. D. Antimicrobial resistance in bacteria isolated from aquatic environments in Brazil: a systematic review. Revista Ambiente \& Água, v. 9, n. 2, p. 239-249, 2014. http://dx.doi.org/10.4136/ambi-agua.1343

NEVES, P. R.; MAMIZUKA, E. M.; LEVY, C. E.; LINCOPAN, N. Pseudomonas aeruginosa multirresistente: um problema endêmico no Brasil. Jornal Brasileiro de Patologia e Medicina Laboratorial, v. 47, n. 4, p.409-420, 2011. https://dx.doi.org/10.1590/S167624442011000400004

NG, L. K.; MARTIN, I.; ALFA, M.; MULVEY, M. Multiplex PCR for the detection of tetracycline resistant genes. Molecular and cellular probes, v. 15, n. 4, p. 209-215, 2001. https://doi.org/10.1006/mcpr.2001.0363

OH, H.; STENHOFF, J.; JALAL, S.; WRETLIND, B. Role of efflux pumps and mutations in genes for topoisomerases II and IV in fluoroquinolone-resistant Pseudomonas aeruginosa strains. Microbial Drug Resistance, v. 9, n. 4, p. 323-328, 2003. https://doi.org/10.1089/107662903322762743

OLIVEIRA, S. S. A.; SORGINE, M. H. F.; BIANCO, K.; PINTO, L. H.; BARRETO, C.; ALBANO, R. M.; CLEMENTINO, M. M. Detection of human faecal contamination by nifH gene quantification of marine waters in the coastal beaches of Rio de Janeiro, Brazil. Environmental Science and Pollution Research, v. 23, n. 24, p. 25210-25217, 2016. https://doi.org/10.1007/s11356-016-7737-3

PAL, C.; ASIANI, K.; ARYA, S.; RENSING, C.; STEKEL, D. J.; LARSSON, D. J.; HOBMAN, J. L. Metal resistance and its association with antibiotic resistance. Advances $\begin{array}{llllll}\text { in microbial physiology, } & \text { v. 70, p. 261-313, }\end{array}$ https://doi.org/10.1016/bs.ampbs.2017.02.001

PASCHOAL, R. P.; CAMPANA, E. H.; CORRÊA, L. L.; MONTEZZI, L. F.; BARRUETO, L. R.; DA SILVA, I. R.; PICÃO, R. C. Concentration and variety of carbapenemase producers in recreational coastal waters showing distinct levels of pollution. Antimicrobial Agents and Chemotherapy, v. 61, n. 12, p. e01963-17, 2017. https://dx.doi.org/10.1128/AAC.01963-17

PETIT, F.; BERTHE, T.; BUDZINSKI, H.; LECLERCQ, R.; CATTOIR, V.; ANDREMONT, A.; DENAMUR, E. Vulnerability and Resilience of Estuaries to Contamination by Antibiotics and Antibiotic-Resistant Bacteria: A Challenge for the Next Decade. Vulnerability of Coastal Ecosystems and Adaptation, p. 65-93, 2014. https://doi.org/10.1002/9781119007739.ch2

POIREL, L.; NAAS, T.; LE THOMAS, I.; KARIM, A.; BINGEN, E.; NORDMANN, P. CTXM-type extended-spectrum $\beta$-lactamase that hydrolyzes ceftazidime through a single amino acid substitution in the omega loop. Antimicrobial Agents and Chemotherapy, v. 45, n. 12, p. 3355-3361, 2001. https://dx.doi.org/10.1128/AAC.45.12.3355-3361.2001

POIREL, L.; RODRIGUEZ-MARTINEZ, J. M.; MAMMERI, H.; LIARD, A.; NORDMANN, P. Origin of plasmid-mediated quinolone resistance determinant QnrA. Antimicrobial $\begin{array}{llllllll}\text { Agents and Chemotherapy, } & \text { v. 49, n. 8, p. 3523-3525, } 2005 .\end{array}$ https://dx.doi.org/10.1128/AAC.49.8.3523-3525.2005 
POTRON, A., POIREL, L.; NORDMANN, P. Origin of OXA-181, an emerging carbapenemhydrolysing oxacillinase, as a chromosomal gene in Shewanella xiamenensis. Antimicrobial Agents and Chemotherapy, 2011. http://dx.doi.org/10.1128/AAC.00681-11

PRUDEN, A.; ARABI, M.; STORTEBOOM, H. N. Correlation between upstream human activities and riverine antibiotic resistance genes. Environmental Science \&

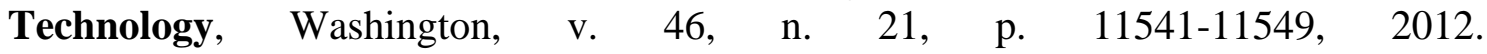
https://doi.org/10.1021/es302657r

QUADRA, G. R.; DE SOUZA, H. O.; DOS SANTOS COSTA, R.; DOS SANTOS FERNANDEZ, M. A. Do pharmaceuticals reach and affect the aquatic ecosystems in Brazil? A critical review of current studies in a developing country. Environmental Science and Pollution Research, v. 24, n. 2, p. 1200-1218, 2017. https://doi.org/10.1007/s11356-016-7789-4

RIO GRANDE DO SUL. Secretaria do Ambiente e Desenvolvimento Sustentável. Bacia hidrográfica do rio Tamandai. 2017. Available at: http://www.sema.rs.gov.br/baciahidrografica-do-rio-tramandai/. Access: Aug. 29, 2017.

SINGH, R.; SWICK, M. C.; LEDESMA, K. R.; YANG, Z.; HU, M.; ZECHIEDRICH, L.; TAM, V. H. Temporal interplay between efflux pumps and target mutations in development of antibiotic resistance in Escherichia coli. Antimicrobial Agents and Chemotherapy, 2012. https://dx.doi.org/10.1128/AAC.05693-11

STALDER, T.; BARRAUD, O.; CASELlAS, M.; DAGOT, C.; PLOY, M. C. Integron involvement in environmental spread of antibiotic resistance. Frontiers in Microbiology, v. 3, p. 119, 2012. https://doi.org/10.3389/fmicb.2012.00119

SWICK, M. C.; MORGAN-LINNELL, S. K.; CARLSON, K. M.; ZECHIEDRICH, L. Expression of multidrug efflux pump genes acrAB-tolC, mdfA, and norE in Escherichia coli clinical isolates as a function of fluoroquinolone and multidrug resistance. Antimicrobial Agents and Chemotherapy, v. 55, n. 2, p. 921-924, 2011. https://dx.doi.org/10.1128/AAC.00996-10

TALUKDAR, P. K.; RAHMAN, M.; RAHMAN, M.; NABI, A.; ISLAM, Z.; HOQUE, M. M.; ISLAM, M. A. Antimicrobial resistance, virulence factors and genetic diversity of Escherichia coli isolates from household water supply in Dhaka, Bangladesh. PloS One, v. 8, n. 4, p. e61090, 2013. https://doi.org/10.1371/journal.pone.0061090

WANG, P.; CHEN, B.; YUAN, R.; LI, C.; LI, Y. Characteristics of aquatic bacterial community and the influencing factors in an urban river. Science of the Total Environment, v. 569, p. 382-389, 2016. https://doi.org/10.1016/j.scitotenv.2016.06.130

WINKWORTH-LAWRENCE, C.; LANGE, K. Antibiotic resistance genes in freshwater biofilms may reflect influences from high-intensity agriculture. Microbial Ecology, v. 72, n. 4, p. 763-772, 2016. https://doi.org/10.1007/s00248-016-0740-x

WOODFORD, N.; ELLINGTON, M. J.; COELHO, J. M.; TURTON, J. F.; WARD, M. E.; BROWN, S.; LIVERMORE, D. M. Multiplex PCR for genes encoding prevalent OXA carbapenemases in Acinetobacter spp. International Journal of Antimicrobial agents, v. 27, n. 4, p. 351-353, 2006. https://doi.org/10.1016/j.ijantimicag.2006.01.004 
XU, Y.; GUO, C.; LUO, Y; LV, J.; ZHANG, Y.; LIN, H.; XU, J. Occurrence and distribution of antibiotics, antibiotic resistance genes in the urban rivers in Beijing, China. $\begin{array}{llllll}\text { Environmental Pollution, } & \text { v. 213, p. 833-840, }\end{array}$ https://doi.org/10.1016/j.envpol.2016.03.054

YANG, Y.; XU, C.; CAO, X.; LIN, H.; WANG, J. Antibiotic resistance genes in surface water of eutrophic urban lakes are related to heavy metals, antibiotics, lake morphology and anthropic impact. Ecotoxicology, v. 26, n. 6, p. 831-840, 2017. https://doi.org/10.1007/s10646-017-1814-3

YONEDA, K.; CHIKUMI, H.; MURATA, T.; GOTOH, N.; YAMAMOTO, H.; FUJIWARA, H.; NISHINO, T.; SHIMIZU, E. Measurement of Pseudomonas aeruginosa multidrug efflux pumps by quantitative real-time polymerase chain reaction. FEMS Microbiology Letters, v. 243, n. 1, p. 125-131, 2005. https://doi.org/10.1016/j.femsle.2004.11.048

YOUNG, S.; JUHL, A.; O'MULLAN, G. D. Antibiotic-resistant bacteria in the Hudson River Estuary linked to wet weather sewage contamination. Journal of Water and Health, $v$. 11, n. 2, p. 297-310, 2013. https://doi.org/10.2166/wh.2013.131

XAVIER, D. E.; PICÃO, R. C.; GIRARDELLO, R.; FEHLBERG, L. C.; GALES, A. C. Efflux pumps expression and its association with porin down-regulation and $\beta$-lactamase production among Pseudomonas aeruginosa causing bloodstream infections in Brazil. BMC Microbiology, v. 10, n. 1, p. 217, 2010.

ZUANAZZI, P. T.; BARTELS, M. Estimativas para a população flutuante do Litoral Norte do RS. Porto Alegre: FEE, 2016. 